\title{
Mineralogical signs of rare-metal and semi-precious ore mineralization in the Murzinskaya-Aduyskaya beryllium (gemstone) subprovince
}

\author{
M. P. Popov
}

\begin{abstract}
The paper considers problems of establishing mineralogical signs of rare-metal and semi-precious ore mineralization in the territory of Murzinskaya-Aduyskaya beryllium (gemstone) subprovince, which is part of Murzinsko-AdamovskoMugodzharskaya rare-metal zone. Beryllium specialization of subprovince is caused by the extensive development of 260-300 mln years old collisional granites enriched with beryllium, tantalum, lithium, cesium, tungsten. Beryllium mineralization on the studied objects is timed to Apo ultramafic or Apo mafic glimmerites, which occur along the eastern contact of Murzinskiy (Glinskoye, Verhne-Susanskoe), Aduyskiy (deposits and occurrences of Ural emerald band) and Kamensky (Mines of Kuznetsov, Kamenskoye) Upper Paleozoic granite massifs. At the stage of general search, minerals-indicators of ore-bearing are most interesting. These issues are a part of search mineralogy researches, aimed at the development of mineralogical search criteria of the mineral deposits. As a result of the works author establishes mineralogical characteristics and patterns, which one can use for search of raremetal and semi-precious ore mineralization: direct search mineralogical signs on the territory of Murzinskaya-Aduyskaya beryllium (gemstone) subprovince are findings of primary beryllium minerals (beryl, emerald, chrysoberyl, alexandrite, phenacite, euclase) and findings of mica veins and complexes, preferably ones that have phlogopite composition; indirect mineralogical signs are findings of secondary beryllium minerals (bavenite, bertrandite, Be-margarit, euclase); pink and purple fluorites, encountered in mica complexes within Murzinskaya-Aduyskaya gemstone subprovince, can be a direct mineralogy sign of semi-precious mineralization (emerald, chrysoberyl, alexandrite); positive europium anomalies in fluorite in the exploratory work are an indirect indication of the ore beryl mineralization; upon finding high positive anomalies of $\mathrm{BeO}$, detected by gamma-neutron and photoneutron methods at the operational exploration stage, one should check them using mineralogical methods (visual inspection, X-ray analysis) to determine the presence of secondary minerals of beryllium (bavenite, bertrandite) or minerals of fragile mica group, bityite-Be-margarit.
\end{abstract}

Keywords: Ural; rare metal deposits; emerald; beryl; alexandrite; gemstones.

\section{ntroduction}

Murzinskaya-Aduyskaya beryllium (gemstone) subprovince is a part of East-Ural rare-metal province, which covers exocontact zones of large batholiths of Late Paleozoic granites of Eastern Ural uplift [1]. Beryllium specialization of subprovince is caused by the extensive development of 260 $300 \mathrm{mln}$ years old collisional granites enriched with beryllium, tantalum, lithium, cesium, tungsten [2]. One can find description of deposits and displays of gems on the territory of Murzinskaya-Aduyskaya beryllium (gemstone) subprovince in the works of G. N. Vertushkov (1932), M. B. Arinshteyn (1983), A. S. Talantsev (1988), Ye. F. Emlin (2002) and others.

Ural emerald band (UEB) is located on the eastern slope of the Middle Urals, in Asbest area of Sverdlovsk region. These deposits were developed almost continuously since 1831. In the period after World War II and before the discovery of large hydrothermal deposits of beryllium at the Far East, Ural emerald mines were one of the main sources of this strategic raw material in the USSR. Recently, Russian emeralds began to appear in jewelry more often. In this regard, the problem of finding new sources of emerald and other semiprecious beryllium materials in the Middle Urals has again become relevant, particularly the idea of continuation of the Ural emerald band to the north and south of the known deposits of Emerald Mines.

Ural emerald band, the part of the Murzinskaya-Aduyskaya beryllium (gemstone) subprovince, is the world famous ore region with largest in Russia deposits of beryllium ore and gemstones: emerald, alexandrite and phenacite. Along with the industrial and economic importance of the Ural Emerald Mines (UEB), as the only supplier in Russia emeralds and alexandrite, they play a major part as a source of various mineral specimens for thematic collections, which have an increased demand among collectors, educational institutions and museums all over the world (Fig. 1).

Tectonic situation area UEB is characterized by an abundance of different ages and of different orders of structures of stretching and compression, powerful crushing zones and block structure. Along the eastern contact of Murzinsko-Aduyskiy anticlinorium runs the deep Susansky submeridional strike rift that is a border between Murzinsko-Aduyskiy anticline and Alapaevsko-Rezhevskaya structure [1].

Geological structure

Murzinskaya-Aduyskaya gemstone subprovince occupies the eastern and south-eastern part of the East-Ural megazone. Beryllium mineralization on the studied objects is timed to Apo ultramafic or Apo mafic glimmerites, which occur along the eastern contact of Murzinskiy (Glinskoye, Verhne-Susanskoe deposits), Aduyskiy (deposits and occurrences of Ural emerald band) and Kamensky (Zarechnoye, Kamenskoye) Upper Paleozoic granite massifs (Fig. 1). Rift has a discontinuous NW-trending violations (azimuth $304^{*}$ ), which are broken by systems of younger sublatitudinal cracks that have usually shallow slope along the azimuth NNW-304* [3]. Their inception occurred in the late stages of the granite massifs formation. Their inception occurred in the late stages of granite massifs formation. Northwest rifts relate to the shear type, they are fall sustained. Sublatitudinal cracks belong to the stretching cracks and their length is small, but in accordance with the plan of tectonic deformations, they parted more often than the north-west [4].

Typical for the UEB area is metamorphic zoning from high levels of amphibolite facies to the weakly metamorphosed rocks of the greenschist facies. Under the influence of pneumatolytic-hydrothermal processes associated with granitic intrusions, the whole complex of deposits of rocks and the entire region undergone metasomatic change in varying degrees. The most complete development acquires alkaline (potassium) metasomatism, during which almost all the rocks are exposed to phlogopitization in varying degrees. In the contact zones of granite, together with amphibolites, biotite rims form, goes the formation of actinolite and tremolite, and albitization of potassium feldspar (microcline), and carbonaceous-siliceous shales graphitize. Processes of carbonation and talking develop in the ultramafic rocks, associated with the exposure of hydrothermal with additional $\mathrm{CO}_{2}$ to these rocks [5].

The field Glinskoye and the manifestation of the Verhne-Susanskoe beryllium mineralization is localized among lenticular bodies represented as talc-actinolite, talc-tremolite, and talc-carbonate schists. Veins of mica and pegmatoids cut talc rocks. Glimmerites mainly consist of phlogopite (90-100\%), muscovite takes up to $5 \%$ of the rock volume, accessory minerals are beryl, tourmaline, chrysoberyl, corundum, apatite, fluorite, relics of chrome-spinel, zircon. Pegmatoids are presented by tourmaline-muscovite-feldspar-quartz veins. Beryl crystals are found on the contacts of pegmatoids veins with mica, chrysoberyl is found in mica.

Emerald-beryl and alexandrite-chrysoberyl-phenacite deposits and occurrences of UEB are located in metamorphic stratum consisting of amphibolite, talc-actinolite and talc schists. Ultramafic rocks occur among the enclosing rocks. Mica veins containing emerald, and alexandrite-chrysoberylphenacite mineralization usually cut these ultramafics. Glimmerites consist mainly of phlogopite, as well as varying amounts of tourmaline, talc, plagioclase, amphibole of tremolite-actinolite series, chlorite, apatite, and fluorite.

Manifestation of green beryl Zarechnoye is localized in the zone of intensely metamorphosed and hydrothermally processed rocks represented by chlorite, sericite, chlorite, sericite, phlogopite, chlorite and other schists. Eastwards, this area is gradually transformed into chlorite-feldspar metaschists that in the northern part of the site are breached by the body of melanocratic amphibole gabbro. From the West, the band of outputs of leucocratic two-mica gneissose granites limits the vein zone. Beryl mineralization exists in sericitechlorite-phlogopite and quartz-feldspar veins.

Materials and methods of research

The study is based on the materials that author collected in the field seasons from 1998 to 2012 years on deposits and manifestations of UEB. Author collected most of the material during studying of mineralogy of the Mariinsky deposit.

Author conducted the study of ontogeny of minerals and their relationship visually, using a magnifying glass MBS-10 and a scanning microscope JCXA-733 Superprobe. The study was conducted at the Institute of Mineralogy Ural Branch of the Russian Academy of Sciences, Miass (analyst L. A. Pautov). All features and ontogenetic relationships minerals were recorded photographically.

$\mathrm{X}$-ray analysis consisted of obtaining the diffraction pattern of minerals and its identification with the reference values. Obtaining the diffraction pattern depended on the amount of material studied and the chosen method - photographic or diffractometal. Photographic method used a material as a mineral powder shaped into a ball. Survey conducted analyst on $\mathrm{FeKa}$ radiation device URS-2.0 in the chamber RKD-57.3 mm (analyst S. G. Sustavov, Ural State Mining University). The accuracy of determining the position of the lines on the Debye photograph estimated at $0.15 \mathrm{~mm}$. Analyst conducted packing of the membrane in an asymmetrical way. In the presence of a relatively large amount of material (3-5 mg or more), analysts carried out $\mathrm{X}$-ray examination on a DRON-2.0 unit on $\mathrm{CuK}^{*}$-radiation with a graphite monochromator (analysts Sapozhnikova N. G., Ural State Mining University, and L. A. Pautov, Museum of A. E. Fersman Russian Academy of Sciences). 


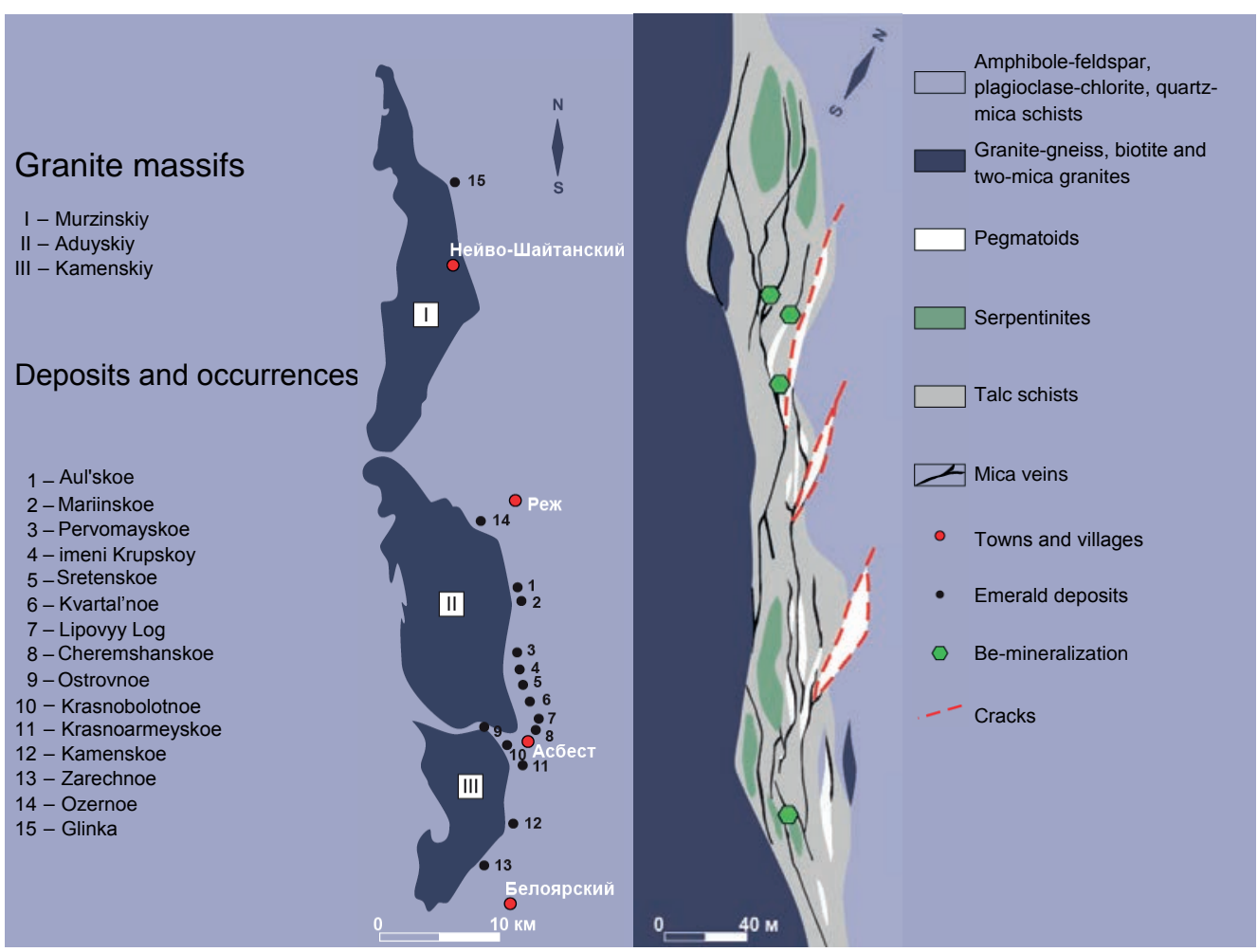

Figure 1. Layout of deposits and occurrences of beryl and gems (emeralds, alexandrite) within Murzinskaya-Aduyskaya semiprecious subprovince.

Identification powdergramms was conducted by using X-RAY program on a personal computer. In some cases, identification of minerals was conducted using comparison with standard radiographs.

To study the microelement composition of fluorite mineral monofraction we selected eight monofractions of mineral with a different color (colorless, blue, green, light brown, dark brown, brown, purple and violet) from different areas of the Mariinskiy deposit. The analytical group of Yu. L. Ronkin (Institute of Geology and Geochemistry of the Ural Branch of the Russian Academy of Sciences) conducted the ecomposition of monofractions and their analysis on mass spectrometer Element 2.

Results of research

A study of alexandrite glimmerites, established direct mineralogical indications [6]. These formations with chrysoberyl and phenacite differ from emerald glimmerites by composition, color and heterogeneity. They form phlogopite and phlogopite-fluorite veins of greenish-gray and greenish-brown color in which chlorite content varies from 10-30\% to 70-90\%. Glimmerites are denser and have more parallel scales, but are only slightly schistosed and are less corrugated than emerald.

Mineral associations, that are direct search signs for the emerald glimmerites, predominantly consist of emerald, beryl, plagioclase, and fluorite. Alexandrite glimmerites usually have the following associations: alexandrite, chrysoberyl, phenacite, margarit, tourmaline (dravite) [6].

The experience of the author in later beryllium mineralization [7] tells that findings of secondary beryllium minerals (bavenite, bertrandite) or of fragile mica group minerals (bityite - Be-Margarit) are as a direct search attributes for the semi-precious and beryl mineralization. Under the microscope, one can see how though the longitudinal, diagonal, rarely transverse cracks in beryllium, bavenite developes. Furthermore, it grows on the verge of beryllium. In the later stages of the hydrothermal process mineral is replaced by bertrandite. The author found that behoit and klinobehoit grow on bavenite. By the time of allocation bavenite is the latest of all minerals associated with them, except for a late chlorite, epidote, analcime.

At the Mariinskiy deposit, the author describes the following color differences of fluorite: brown, colorless, green, blue, pink and purple. Among all these groups two main colors of fluorite stand out (pink and purple), both of which can serve as a direct search sign of the ore beryllium mineralization (beryl, emerald, alexandrite); both are prone to rapid bleaching up to the gray color on the sunny surface. Pink fluorite is most common in rich beryl and powerful quartz-plagioclase veins, vein metasomatic zones of the Northern and central regions of the Mariinskiy deposit. It is virtually non-existent in the South flank of the deposit (even in the rich veins) and almost never occurs in small veins and poor areas. Purple fluorite is always associated with phlogopite and margarit. Is most commonly "seals" (Fig. 2, 3) chromium-containing mineral association (emerald, alexandrite). All other color variations are not directly connected with the main mineralization, as they formed later and are a part of later mineralization.

Fluorites of the Mariinskiy deposit have a number of characteristic and distinctive features according to the trace element composition. At the same for all types of fluorite typomorphic feature is the enrichment of the mineral with elements of the mafic-ultramafic formations (for example, the amount of chromium varies from 262 to $317 \mathrm{~g} / \mathrm{t}$, regardless of mineral color) (Table). Apparently, this is due to the fact that in the final stage of formation of all of mineral parageneses during crystallization fluids from the surrounding rocks started to participate, which are mainly represented by serpentinites and Apo ultramafic metasomatites. In this case, the calcium halide is formed directly in the matrix of Apo ultramafic substrate and has a trace element composition that is typical to many serpentinites [8].

According to the distribution of lanthanides, author can divide colorfu fluorites of the Mariinskiy deposit into three types: high, intermediate and a low content of REE (Fig. 4). In the first type falls green fluorite and all brown tones. They are characterized by a gradual drop in REE (from heavy to light elements) and the presence of a weak positive anomaly of europium. Lanthanide concentration therein varies from 82 to $116 \mathrm{~g} / \mathrm{t}$. The ratio La/ $\mathrm{Yb}$ is equal to $0,34-0,54$. These values are typical for fluorites from granitic pegmatites $(0,8)$ and acidic rocks $(0,3)$ [9]. In the second type fall colorless and blue fluorites, they are characterized by a sharp drop in of REE (from heavy to light elements). Colorless fluorite has a strong negative anomaly of europium, while there are no anomalies in the blue. The ratio $\mathrm{La} / \mathrm{Yb}$ is equal to $0.03-0.07$. Lanthanide concentration therein varies from 14 to $21 \mathrm{~g} / \mathrm{t}$. It is possible that the first and second types of fluorite are just different generations, formed on the same substrate of rocks, because of what the trends configuration of REE distribution is very similar and differs only in the concentration of rare earths. Thus, the first type fluorite completed the formation of pegmatites, and the second type has sealed the quartz-plagioclase veins that were formed by first albitization of rocks [8]

Purple fluorite applies to 6he third type. It has an extremely low content of REE (up to $5 \mathrm{~g} / \mathrm{t}$ ). This fluorite is characterized by a gradual increase from heavy to light elements and the presence of a sharp positive anomaly of europium. $\mathrm{La} / \mathrm{Yb}$ ratio is equal to 10.2 . It is interesting that such a high ratio is characteristic for syenite pegmatites and alkaline rocks, maybe this is due to the appearance of an alkaline environment during the crystallization of purple fluorite. There are no descriptions of REE distributions similar to the third type of fluorite in the literature, although it is strongly reminiscent with the trends of the lanthanides from Bazhenovskoye apoharzburgite serpentinites [8]. 


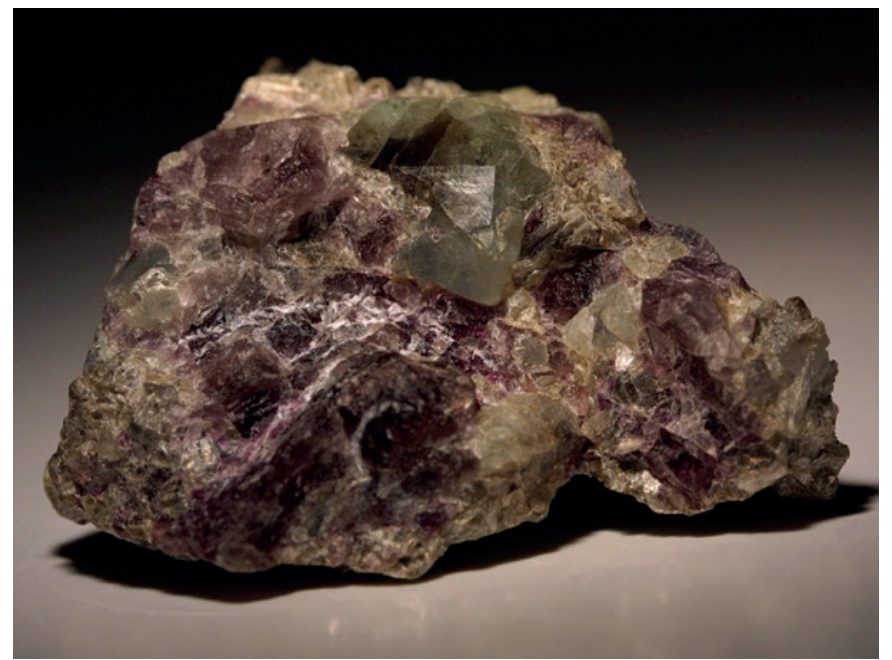

Figure 2. The crystals of chrysoberyl (green) in fluorite (purple).

\section{Discussion}

At an early stage of identifying and characterizing of semi-precious and rare-metal beryllium, mineralization is of great importance to use mineralogical characteristics. At the stage of general search, mineralsindicators of ore bearing are most interesting. These issues are a part of search mineralogy researches, aimed at the development of mineralogical search criteria of the mineral deposits. There are the following mineralogical search features: a) resistant association of the minerals; "Prohibited" combinations of minerals; minerals of ore indicators or a specific process; morphological features of minerals [9]. Mineralogical features in conjunction with geological and geochemical elements of these models allow estimating the formation type of mineralization, of stages of its formation, the presence of rich or poor ores.

Direct minerals-indicators related to the nature of certain mineral bodies and near-ore halos, indirect - with medium of ore mineralization. According to the theory proposed by N. P. Yushkin, minerals-indicators are divided into three categories by search functions [10]:

- useful (ore) minerals are direct indicators of ore-bearing, have the greatest search value and serve as a reliable guide for prospecting one of the methods to determine the halo of minerals (boulders, detritus, schlich). Finding such minerals must be documented. On the territory of beryllium Murzinskaya-Aduyskaya subprovince these are beryl, chrysoberyl, emerald, alexandrite, phenacite;

minerals, related to useful minerals, i. e., are in a close genetic relationship the latest. For example, the phlogopite, plagioclase, chlorite or secondary beryllium minerals - bavenite, bertrandite;

- minerals, associated with useful minerals (minerals-satellites), which are used for search purposes and are the most important indicators of the search. Minerals satellites may be varied in their nature and in their search value. On the territory of subprovince these are fluorite, apatite, talc, margarit.

Justification of each new mineralogical indicator is equivalent to the development of a new search method. In addition to high informativeness, one should maximize flexibility, possibility of obtaining using express methods, providing mass measurement indicator minerals parameters [10].

Ore deposition conditions find their reflection in the formation of specific, natural mineral associations, typical for this situation mineralsindicators that provide useful information about the processes of formation of ore bodies. Earlier in deposits and manifestations of the Ural emerald band O. Ye. Chizhik and Z. V. Lekukh identified the following groups of mineralogical attributes [11].

The first group of signs includes the composition of rock-forming minerals in the veins of glimmeites. This is phlogopite (90\%) and impurities are present as talc, chlorite and actinolite (up to $10-50 \%$ ). A positive sign of secondary semi-precious and rare metal raw materials within MurzinskayaAduyskaya beryllium subprovince is discovery of glimmerites of mainly phlogopite composition.

The second group of symptoms that can be treated as a direct search feature - it is the presence of one of beryllium minerals in glimmerites (beryl, emerald, chrysoberyl, phenacite).

In research [12], the description of the local search signs and criteria for the deposits of jewelry beryl, as a direct mineralogical and petrographic features authors provide finds of beryl that has emerald green color, regardless of the size, transparency and perfect crystals (emeralds). Indirect signs include mineralogical finds of satellite minerals of a variety of beryl jewelry (including emeralds), well described in the scientific literature. Mineralogical

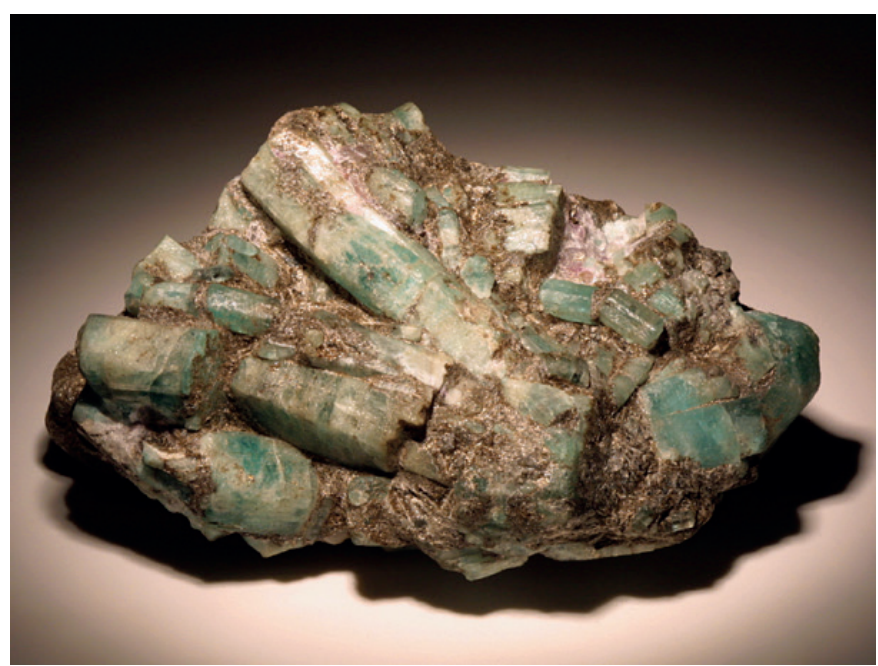

Figure 3. Discharge of purple fluorite among green beryl crystals.

and petrographic sign of emerald deposit is the existence of zones and veins of glimmeites of significantly (over 90\%) phlogopite composition, with an admixture of talc, chlorite, actinolite and containing phenacite, chrysoberyl, Be-margarit $[12,13]$.

Previously we examined mineralogical emerald signs of ore bodies at the Mariinsky deposit, based on the variations of the properties of Ca-containing minerals (apatite, plagioclase, fluorite) [14, 15].

Indirectly, the presence of ore (useful) beryllium mineralization indicates higher values of $\mathrm{BeO}$ in the surrounding rocks, fixed by chemicalanalytical methods, or gamma-neutron and photoneutron methods. Therefore, in the early stages of search operations on rare-metal and semi-precious mineralization one uses special geophysical instruments - berylometers. They detect beryllium by irradiation of rocks with radioactive isotopes with the subsequent registration of secondary radiation. In the later stages of exploration (operational, advanced) and geological exploration, starting with detailed searches berylometers readings should be checked or supplemented with mineralogical studies (visual diagnostics, X-ray analysis). According to the experience of the author at the Mariinskiy deposit $\mathrm{BeO}$ some anomalies were connected mostly to the development of late beryllium mineralization, whereas the main mineralization (beryl, emerald) was in the side [7]. One can frequently observe it in tectonically weakened zones.

The following mineral associations are commonly used at the deposits of mica type located outside of Russia, as a mineralogical signs of the gemstone mineralization:

Changes in the composition of tourmaline (dravite) as a sign on emerald mineralization in the Yukon territory (Canada) [16].

- Quartz-tourmaline mineralization in phlogopite shales, as an indicator on emeralds at Kafubu deposit (Zambia) $[17,18]$.

Findings of Ni-Cr containing muscovite and tourmaline are search signs at geological exploration on the emerald mineralization on Swat deposit (Pakistan) [19].

- On some deposits of Madagascar, emerald mineralization occurs at the contact of granitic pegmatites from the ultrabasic rocks, where the productive

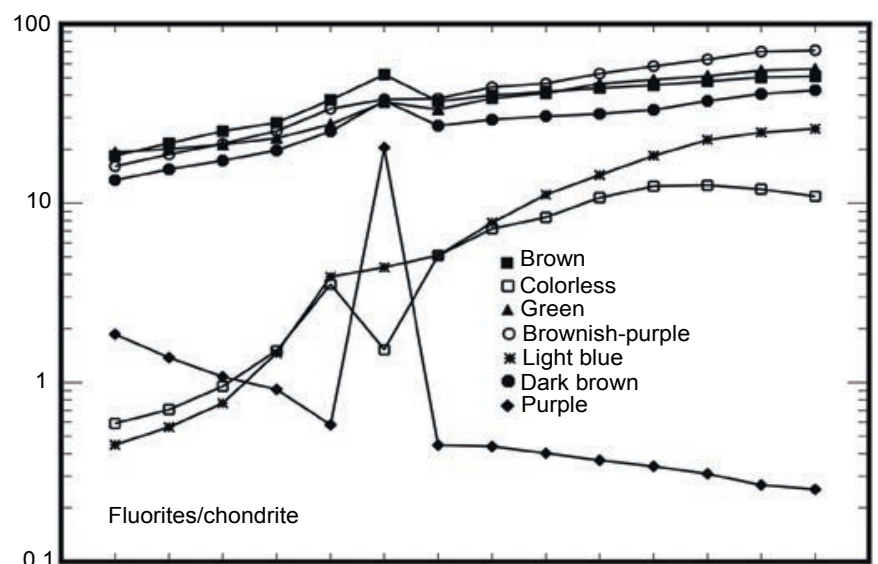

La $\mathrm{Ce} \quad \mathrm{Pr} \mathrm{Nd} \quad \mathrm{Sm}$ Eu Gd Tb Dy $\mathrm{Ho}$ Er $\mathrm{Tm} \quad \mathrm{Yb} \quad \mathrm{Lu}$

Figure 4. Distribution of REE in fluorites of Mariinskiy deposit. 
Microelement composition ( $g / t)$ of fluorites of Mariinskiy deposit.

\begin{tabular}{|c|c|c|c|c|c|c|c|}
\hline \multirow{2}{*}{ Element } & \multicolumn{7}{|c|}{ Mineral color } \\
\hline & Colorless & Brown & Green & Light blue & Purple & Brownish-purple & Dark brown \\
\hline $\mathrm{Li}$ & 0,08 & 0,14 & 0,49 & 0,02 & 0,04 & 0,06 & 0,12 \\
\hline $\mathrm{Be}$ & 1,94 & 1,97 & 1,78 & 1,77 & 1,86 & 2,23 & 2,04 \\
\hline $\mathrm{P}$ & 178,00 & 171,00 & 171,00 & 153,00 & 142,00 & 177,00 & 163,00 \\
\hline Sc & 1,56 & 1,51 & 1,48 & 1,38 & 1,35 & 1,51 & 1,47 \\
\hline $\mathrm{Ti}$ & 83,90 & 15,50 & 10,50 & 8,67 & 4,93 & 7,47 & 8,88 \\
\hline V & 72,80 & 81,70 & 89,30 & 70,00 & 73,20 & 69,20 & 75,50 \\
\hline $\mathrm{Cr}$ & 295,00 & 317,00 & 312,00 & 262,00 & 265,00 & 287,00 & 316,00 \\
\hline $\mathrm{Mn}$ & 10,20 & 76,20 & 10,50 & 2,13 & 1,09 & 36,30 & 38,70 \\
\hline Co & 4,86 & 4,86 & 5,41 & 4,09 & 3,92 & 4,54 & 4,51 \\
\hline $\mathrm{Ni}$ & 80,90 & 82,00 & 96,10 & 71,70 & 68,00 & 79,10 & 78,60 \\
\hline $\mathrm{Cu}$ & 0,93 & 0,53 & 0,64 & 0,26 & 0,29 & 0,53 & 0,73 \\
\hline $\mathrm{Zn}$ & 2,16 & 1,22 & 1,28 & 0,98 & 1,07 & 1,24 & 1,15 \\
\hline $\mathrm{Ga}$ & 0,30 & 0,13 & 0,20 & 0,09 & 0,08 & 0,12 & 0,13 \\
\hline $\mathrm{Ge}$ & 2,07 & 2,38 & 2,43 & 2,18 & 2,22 & 1,68 & 1,95 \\
\hline As & 11,90 & 13,20 & 13,00 & 10,30 & 10,50 & 11,60 & 12,40 \\
\hline $\mathrm{Rb}$ & 0,41 & 0,17 & 3,86 & 0,08 & 0,14 & 0,10 & 0,14 \\
\hline $\mathrm{Sr}$ & 157,00 & 689,00 & 338,00 & 59,30 & 58,40 & 575,00 & 592,00 \\
\hline$Y$ & 96,60 & 151,00 & 212,00 & 94,00 & 2,11 & 248,00 & 98,80 \\
\hline $\mathrm{Zr}$ & 1,87 & 0,30 & 0,17 & 0,16 & 0,10 & 0,14 & 0,11 \\
\hline $\mathrm{Nb}$ & 0,20 & 0,05 & 0,10 & 0,03 & 0,02 & 0,03 & 0,04 \\
\hline Mo & 0,98 & 0,30 & 0,55 & 0,13 & 0,45 & 0,51 & 0,22 \\
\hline Sn & 0,39 & 0,33 & 0,43 & 0,36 & 0,32 & 0,35 & 0,36 \\
\hline $\mathrm{Sb}$ & 0,03 & 0,02 & 0,03 & 0,01 & 0,01 & 0,01 & 0,01 \\
\hline $\mathrm{Te}$ & 0,03 & 0,04 & 0,03 & 0,02 & 0,02 & 0,03 & 0,03 \\
\hline I & 0,56 & 0,57 & 0,59 & 0,55 & 0,52 & 0,55 & 0,55 \\
\hline Cs & 0,04 & 0,03 & 0,18 & 0,01 & 0,05 & 0,01 & 0,04 \\
\hline $\mathrm{Ba}$ & 5,67 & 1,54 & 1,69 & 0,90 & 0,56 & 0,88 & 1,09 \\
\hline $\mathrm{La}$ & 0,19 & 6,04 & 6,33 & 0,15 & 0,61 & 5,28 & 4,43 \\
\hline $\mathrm{Ce}$ & 0,61 & 18,70 & 17,37 & 0,49 & 1,19 & 16,20 & 13,39 \\
\hline $\operatorname{Pr}$ & 0,12 & 3,28 & 2,76 & 0,10 & 0,14 & 2,80 & 2,25 \\
\hline $\mathrm{Nd}$ & 0,95 & 17,70 & 14,50 & 0,92 & 0,58 & 15,90 & 12,40 \\
\hline $\mathrm{Sm}$ & 0,72 & 7,63 & 5,60 & 0,79 & 0,12 & 6,82 & 5,10 \\
\hline Eu & 0,12 & 4,02 & 2,82 & 0,34 & 1,57 & 2,93 & 2,87 \\
\hline $\mathrm{Gd}$ & 1,41 & 10,19 & 9,21 & 1,41 & 0,12 & 10,57 & 7,47 \\
\hline $\mathrm{Tb}$ & 0,36 & 1,99 & 1,92 & 0,39 & 0,02 & 2,22 & 1,46 \\
\hline Dy & 2,86 & 14,40 & 14,10 & 3,83 & 0,14 & 16,00 & 10,50 \\
\hline Ho & 0,83 & 3,38 & 3,57 & 1,11 & 0,03 & 4,06 & 2,43 \\
\hline Er & 2,80 & 10,30 & 11,00 & 4,13 & 0,08 & 13,10 & 7,48 \\
\hline $\mathrm{Tm}$ & 0,44 & 1,68 & 1,80 & 0,79 & 0,01 & 2,24 & 1,31 \\
\hline $\mathrm{Yb}$ & 2,63 & 11,1 & 12,1 & 5,46 & 0,06 & 15,4 & 8,97 \\
\hline Lu & 0,37 & 1,73 & 1,90 & 0,88 & 0,01 & 2,42 & 1,45 \\
\hline $\mathrm{Hf}$ & 0,08 & 0,17 & 0,17 & 0,06 & - & 0,18 & 0,11 \\
\hline $\mathrm{Ta}$ & 0,02 & 0,05 & 0,06 & 0,02 & 0,01 & 0,06 & 0,03 \\
\hline W & 3,16 & 0,80 & 0,76 & 0,12 & 0,07 & 0,66 & 0,81 \\
\hline $\mathrm{Re}$ & 0,05 & 0,03 & 0,04 & 0,02 & - & 0,04 & 0,02 \\
\hline $\mathrm{Hg}$ & 0,16 & 0,05 & 0,04 & 0,01 & 0,01 & 0,03 & 0,04 \\
\hline $\mathrm{Pb}$ & 0,55 & 1,01 & 4,85 & 0,08 & 0,72 & 0,16 & 0,16 \\
\hline $\mathrm{Bi}$ & 0,02 & 0,02 & 0,02 & 0,01 & 0,04 & 0,01 & 0,03 \\
\hline Th & 0,08 & 0,17 & 0,03 & 0,01 & 0,02 & 0,10 & 0,12 \\
\hline U & 0,02 & 0,06 & 0,04 & 0,01 & 0,03 & 0,04 & 0,05 \\
\hline
\end{tabular}

signs on emerald mineralization are chlorite, phlogopite, tremolite and plagioclase [20].

As an indirect sign of searching for rare-metal and semi-precious beryllium mineralization in glimmerites in the territory of MurzinskayaAduyskaya beryllium (gemstone) subprovince is possible to use a distinctive feature of purple fluorite - a very low content of REE (not more than $5 \mathrm{~g} / \mathrm{t}$ ). This fluorite is characterized by a gradual increase from heavy to light elements and the presence of a sharp positive anomaly of europium (Fig. 4). He thus stands out among all the color differences, met at the Mariinskiy deposit [8].

Conclusions

Direct search mineralogical signs on the territory of Murzinskaya-
Aduyskaya beryllium (gemstone) subprovince are findings of primary beryllium minerals (beryl, emerald, chrysoberyl, alexandrite, phenacite, euclase).

Important direct mineralogical signs of rare-metal and semi-precious beryllium mineralization are discoveries of secondary beryllium minerals (bavenite, bertrandite, Be-margarit, euclase).

Discoveries of glimmerites veins and complexes, preferably phlogopite composition should be considered as an indirect mineralogical signs across the province.

Pink and purple fluorites, encountered in mica complexes within Murzinskaya-Aduyskaya gemstone subprovince, can be a direct mineralogy sign of semi-precious mineralization (emerald, chrysoberyl, alexandrite). 
Upon finding high positive anomalies of $\mathrm{BeO}$, detected by gammaneutron and photo-neutron methods at the operational exploration stage, one should check them using mineralogical methods (visual inspection, $\mathrm{X}$-ray analysis) to determine the presence of secondary minerals of beryllium (bavenite, bertrandite) or minerals of fragile mica group, bityite-Be-margarit.

\section{REFERENCES}

1. Zoloev K. K., Levin V. Ya., Mormil' S. I. 2004, Minerageniya i mestorozhdeniya redkikh metallov, molibdena i vol'frama Urala [Minerageny and deposits of rare metals, molybdenum and tungsten of Urals], Ekaterinburg, $436 \mathrm{p}$.

2. Fershtater G. B. 2001, Granitoidnyy magmatizm i formirovanie kontinental'noy zemnoy kory $v$ khode razvitiya Ural'skogo orogena [Granitoid magmatism and formation of continental crust during the development of the Ural orogen] Litosfera [Litosphere], no. 1, pp. 62-85.

3. Kupriyanova, I. I. 2002, O genezise Malyshevskogo berilliy-izumrudnogo mestorozhdeniya (Sredniy Ural, Rossiya) [On the genesis of emeraldberyllium Malyshevskoe deposit (Middle Urals, Russia)]. Geologiya rudnykh mestorozhdeniy [Mining geology], no. 4, pp. 314-330.

4. Zolotukhin F. F. 1996, Mariinskoe (Malyshevskoe) mestorozhdenie izumruda, Sredniy Ural [Mariinsk (Malyshevskoye) deposit of emerald, Middle Urals] Asbest-Ekaterinburg-St. Petersburg, $70 \mathrm{p}$

5. Mamaev I. N. et al. 1989, Otchet Malyshevskoy geologo-s'emochnoy partii za 1983-1989 gody [Report Malyshevsky geological mapping party for years 19831989]. PO «Uralgeologiya» [JSC "Uralgeology"]. Sverdlovsk, vol. 3, 404 p.

6. Popov M. P. 2013, Ural'skaya khrizoberill-izumrudonosnaya provintsiya [Ural chrysoberyl-emerald province]. Materialy II mezhdunarodnoy nauchnoprakticheskoy konferentsii "Fundamental'nye i prikladnye nauki segodnya", dekabr' 2013 [Proceedings of the II International scientific-practical conference "Fundamental and Applied Science today", December 2013], Moscow, pp. 15-20. 7. Popov M. P. 1999, Pozdneberillievaya mineralizatsiya kak istochnik ogranochnokollektsionnogo syr'ya (Mariinskoe mestorozhdenie, Ural'skie Izumrudnye kopi). Avtoreferat dissertatsii na soiskanie uchenoy stepeni kandidata geologomineralogicheskikh nauk [Later Beryllium mineralization as a source of diamond cutting, the collection of raw materials (Mariinsk deposit Ural Emerald Mines). Synopsis of dissertation for the degree of geological-mineralogical sciences], Ekaterinburg, $35 \mathrm{p}$.

8. Popov M. P., Erokhin Yu. V. 2010, Tipomorfnye osobennosti flyuorita Mariinskogo mestorozhdeniya berilliya (Ural'skie Izumrudnye kopi) [Typomorphic features of fluorite of the Mariinsky deposit of beryllium (Ural Emerald Mines)]. Litosfera [Litosphere], no. 4, pp. 157-162.

9. Bulakh A. G. 2002, Obshchaya mineralogiya [General mineralogy], St. Petersburg, $356 \mathrm{p}$.

\section{Mikhail Petrovich Popov,}

popovm1@yandex.ru

Ural State Mining University

Ekaterinburg, Russia
10. Yushkin N. P. 1989, Osnovnye printsipy poiskovo-otsenochnoy mineralogii [The basic principles of search and assessment of Mineralogy]. Dokl. sov. geologov na XXVIII ses. Mezhdunar. Geol. Kongr. (Vashington, iyul' 1989) [Report by Soviet geologists at the XXVIII session of the International Geological Congress (Washington, DC, July 1989)], Moscow, pp. 158-163.

11. Chizhik O. E., Lekukh Z. V. 1980, O genezise izumrudov v mestorozhdeniyakh slyuditovogo tipa [The genesis of emeralds in mica fields]. Dragotsennye tsvetnye kamni [Precious and colored stones], Moscow, pp. 158-174.

12. Kisin A. Yu., M. P. Popov M. P., Komashchenko S. V. 2011, Spetsifika mestorozhdeniy yuvelirnogo berilla kak osnova prognozno-poiskovogo poiska [Specifics of jewelry beryl deposits as a basis for forecasting and search]. Litosfera [Litosphere], no. 5, pp. 96-104.

13. Laskovenkov, A. F., Zhernakov, V. I., 1995. An update on the Ural Emerald Mines. Gems \& Gemology, 31, No. 2, 106-113.

14. Kupriyanova I. I., Kukushkina O. A., Gryaznov Yu. A., Novikova M. I., Kuvshinova K. A., Lyapunov S. M. 1990, Sopryazhennost' svoystv paragennykh kal'tsiysoderzhashchikh mineralov berillievykh mestorozhdeniy i ikh tipomorfnoe znachenie [Conjugation of properties of the paragenetic calcium minerals of beryllium deposits and their typomorphic significance]. IzV. AN SSSR. Ser. Geol. [Proceedings of the Academy of Sciences of the USSR. Series Geology], no. 9, pp. 71-81.

15. Kupriyanova I. I., Moroshkin V. V. 1987, O vozmozhnosti ispol'zovaniya lyuminestsentnykh svoystv plagioklaza i apatita kak priznakov izumrudonosnost [On the possibility of using the fluorescent properties of plagioclase and apatite as a signs of emeralds]. IzV. AN SSSR. Ser. Geol. [Proceedings of the Academy of Sciences of the USSR. Series Geology]. No, 9, pp. 84-90.

16. Galbraith, C. G., Clarke, D. B., Trumbull, R. B., Wiedenbeck, M. (2009): Assessment of Tourmaline Compositions as an Indicator of Emerald Mineralization at the Tsa da Glisza Prospect, Yukon Territory, Canada. Economic Geology, 104, 5, 713-731.

17. Zwaan, J. C., Seifert, A., Vrána, S., Laurs, B. M., Anckar, B., Simmons, W. B., Falster, A. U., Lustenhouwer, W. J., Muhlmeister, S., Koivula, J. I., GarciaGuillerminet, H., 2005. Emeralds from the Kafubu area, Zambia. Gems and Gemology 41, 116-148.

18. Seifert, A. V., Žáček, V., Vrána, S., Pecina, V., Zachariáš, J., Zwaan, J. C. 2004. Emerald Mineralization in the Kafubu area, Zambia. Bulletin of Geosciences 79, 1-40.

19. Arif, M., Fallick, A. E., Moon, A. E., 1996. The genesis of emeralds and their host rocks from Swat, northwestern Pakistan: a stable-isotope investigation. Mineralium Deposita 31, 255-268.

20. Cheilletz, A., Sabot, B., Marchand, P., De Donato, P., Taylor, B., Archibald, D., Barres, O., Andrianjaffy, J., 2001. Emerald deposits in Madagascar: two different types for one mineralizing event. European Union of Geosciences. Journal of Conference Abstracts 6, 547 . 